\title{
Exploring the Impact of Technological Competence Development on Speed and NPD Program Performance
}

\author{
Nuran Acur ${ }^{1}$, Destan Kandemir ${ }^{2}$, Petra C. de Weerd-Nederhof ${ }^{3}$, and Michael Song ${ }^{4}$ \\ ${ }^{1}$ Strathclyde University, Strathclyde Institute of Operations Management, UK \\ 2 Bilkent University, Departmant of Management, Turkey \\ ${ }^{3}$ University of Twente, Netherlands \\ ${ }^{4}$ Bloch School of Business and Public Administration, University of Missouri-Kansas City
}

Submitted to the JPIM - EIASM Twente Special Issue

July 6, 2009 


\title{
Exploring the Impact of Technological Competence Development on Speed and NPD Program Performance
}

\begin{abstract}
With growing levels of competition across industries, technological competence is increasingly viewed as crucial for businesses to maintain their long-term competitive advantage. Although there are many theoretical arguments about how firms' competences can yield competitive advantage and performance improvement, we have a limited understanding of where the capabilities originate in the context of NPD or what kind of product portfolios, internal climate and strategic alignment are required to build them. Moreover, empirical evidence for technological competence development is limited and comes primarily from case studies, anecdotal evidence, and management impressions. Accordingly, this research addresses these gaps by presenting and testing a conceptual model of technological competence development in NPD. This study makes advances in applying a dynamic capability approach to technological competence development in NPD, and investigates the impact of innovative climate, technological alignment, and project portfolio management on technological competence development as well as NPD speed. Moreover, the factors that might influence NPD program performance are also investigated.

The analysis, based on data collected from 164 firms, shows that a firm's innovative climate, technological alignment and portfolio management are positively associated with technological competence development. While technological alignment was found to be negatively related to NPD speed, portfolio management and technological competence development were found to have positive effects on speed. However, innovative climate had no significant impact on speed. Moreover, technological competence development and portfolio management were found to be positively related to NPD program performance. Finally, the authors found no support for the relationship between speed and NPD program performance.
\end{abstract}




\section{INTRODUCTION}

With the growing levels of competition across industries, technological competence is increasingly viewed as crucial for businesses to maintain their long-term competitive advantage (Atuahene-Gima 2005; Garcia, Calantone and Levine 2003; Li and Calantone 1998; Nelson, 1991). Technological competences urge firms to acquire, develop and use technology to achieve competitive advantage and to stay close to their customers (Hobday and Rush, 2007; McEvily, Eisenhardt and Prescott, 2004). Technological competence development in NPD reflects the values of the 'technological push' which emphasizes the development of technologically superior products and services (Gatignon and Xuereb, 1997). Such competences are intangible and interaction-based, and so are usually difficult for competitors to trade, imitate or duplicate (Coombs and Bierly, 2006; Day 1994; Nelson 1991).

Dynamic capability literature has examined the determinants of technological competence development and their impact on performance. To date, the effect of technological competence on firms' performance has been studied primarily in the technology management literature. These studies have consistently showed that technological competences impact on the best performance (e.g. Coombs and Bierly, 2006; Danneels, 2007; McEvily, Eisenhardt, Prescott, 2004; Pisano, 1994; Zahra, 1996; Song et al., 2005). In other words, firms with superior technological competences tend to be more innovative and thus develop better product performance (McEvily, Eisenhardt, and Prescott, 2004). Although there are many theoretical arguments about how firms' competences can yield competitive advantage and performance improvement, we have a limited understanding of where the capabilities originate or what kind of product portfolios, internal climate and strategic flexibility to search new (technological alignment) are required to build them. On the other hand, evidence for competence development in NPD is limited and comes primarily from case studies, anecdotal evidence, and management impressions (Montoya-Weiss and Calantone 1994; Song et al., 2005). We address these gaps in the research by presenting and testing a conceptual model of technological competence development in NPD.

By synthesizing technology management, strategic management and NPD literature, this study attempts to link technological competence development with the strategic dimensions of firms' dynamic capabilities. This includes portfolio management, technological alignment and innovative climate, and the impact on NPD speed and program performance. In recent research, Parry et al. (2009) studied the impact on perceived cycle time of six variables that reflect a business unit's NPD strategy, NPD environment, product strategy, and NPD process. This paper expands on that research by examining three strategic dimensions of dynamic capabilities and their impact on NPD speed and technological competence development and NPD. This study makes advances in applying a dynamic capability approach to technological competence development by assessing its importance to the relationship between the dimensions of dynamic capability and NPD speed and program performance. The study examines the direct effects of the dynamic capability's dimensions on NPD.

The hypotheses are tested using data collected from 164 American firms. The findings indicate that portfolio management, innovative climate and technological alignment are antecedents to both technological competence development and NPD speed, which in turn are antecedents to NPD programme performance.

The next section of the article reviews the literature, highlighting the importance and

multiple dimensions of technological competence development. Drawing on a dynamic capability perspective, the article advances the relationship between dynamic capabilities dimensions, NPD speed and technological competences development in the NPD context. It then presents a study 
empirically testing these hypotheses, followed by a discussion of findings and their managerial and academic implications.

\section{BACKGROUND}

The notion of competences is rooted in the resource-based, dynamic capability and knowledge-based theories. All of these theories explain how competences, such as technological competences, create competitive advantages in markets; however, they underline different levels of dynamism (McEvily, Eisenhardt, and Prescott, 2004).

The development of a resource-based view (RBV) provides a clearer understanding of when resources and capabilities are likely to have positive effects on new product outcomes and developing/maintaining competitive advantage (Kleinschmidt, de Brentani, and Salomo, 2007; Wernerfelt, 1984). The RBV views the firm as a bundle of resources and emphasizes that firms are heterogeneous due to their unique resources, capabilities and endowments (Barney, 1991; Grant, 1991). The dynamic capabilities view underlines that competences need to change over time to respond to changing environments to attain and sustain competitive advantage (Eisenhardt and Martin, 2000; Helfat, 1997; Sanchez and Heene, 1997; Teece, Pisano, and Shuen, 1997). This view also places more emphasis on learning and innovation (Nelson and Winter, 1982; Prahalad and Hamel, 1990; Teece, Pisano, and Shuen, 1997). The knowledge-based view of the firm suggest that organizations can play a critical role in articulating and applying different types of knowledge (e.g. technological, market) through transfer or replication as well as integration and coordination efforts (Galunic and Rodan, 1998; Grant, 1996; Kogut and Zander, 1992).

Most scholars consider technological competence as a firm's ability to make effective use of technological knowledge and learning to develop and improve products and processes (Kim, 1997; McEvily et al., 2004). Therefore, our approach draws mainly on a dynamic capabilities approach to investigate the role of technological competence development in the new product development context. In a similar vein, we define technological competences, for the purpose of this research, as the set of activities and behaviours implemented to detect and shape opportunities and threats, seize opportunities and maintain competitiveness through enhancing, combining, protecting and, where necessary, reconfiguring firms' tangible and intangible resources.

\section{Conceptual Model}

Dynamic capabilities are seen as a vehicle for creating or renewing the organizational capabilities or specifically technological capabilities of firms (Easterby-Smith and Prieto, 2008; Eisenhardt and Martin, 2000; Teece, Pisano, and Shuen, 1997). Many scholars claim that dynamic capabilities help firms not only to identify opportunities but also to formulate responses to opportunities to implement courses of action (i.e. Easterby-Smith and Prieto, 2008; Eisenhardt and Martin, 2000; Teece, Pisano, and Shuen, 1997). Therefore, investigating performance effects of technological competence development as an element of a firm's strategic dimensions can be approached from the dynamic capabilities perspective (Eisenhardt and Martin, 2000; Teece and Pisano, 1994; Teece, Pisano, Shuen 1997). Furthermore, Teece, Pisano, and Shuen (1997) also emphasize that capabilities can be assembled together from internal and external sources which can also be considered part of a firm's strategic dimensions of dynamic capabilities. Figure 1 shows the internal (i.e. innovative climate, project portfolio management) and external sources of a firm's dynamic capabilities, technological competence and performance constructs. We begin by discussing the study's constructs.

Insert Figure 1 about here 
Three strategic dimensions of dynamic capabilities are considered: positions, path dependency and processes (Schreyögg and Kliesch-Eberl, 2007; Teece and Pisano, 1994; Teece, Pisano, and Shuen 1997). Position refers to a firm's internal and external positions. The internal position associates with the available set of a firm's soft and hard resources (i.e. financial, technological, innovative climate, reputation), whereas external position refers to its specific market position (Teece, Pisano, and Shuen 1997). Innovative climate is considered one of a firm's soft resources (Salomo, Talke, and Stecker, 2008). Employees in an innovative climate are more open to new ideas and more willing to change and adapt to emerging technological and market trends (Hurley and Hult, 1998). Thus, 'internal position' is related to innovative climate.

Path dependency refers to the strategic alternatives available to firms today and also their future directions depending on current paths and how different forces have already shaped their preferences (Schreyögg and Kliesch-Eberl, 2007; Teece and Pisano, 1994). At any time, firms follow certain path dependencies. Specifically, technological path dependencies initiated by a firm's technological choices orientates it into a specific technological trajectory (e.g. Ruttan, 1997; Schilling, 1998). Clearly, 'path dependency' closely relates to technological alignment. Technological alignment refers to a firm's ability to foresee and develop new product technology and related processes. Hence, technological alignment increases an organization's awareness of technological competence development possibilities, which are then communicated to the NPD function through the NPD-technological interface (Li and Calantone, 1998). Accordingly, firms tend to advocate a commitment to a better technological alignment with NPD.

Processes refer to coordinating and integrating available resources (Schreyögg and KlieschEberl, 2007) or organizational learning, local searches, feedback, experience curves and the reconfiguration of resources (Helfat and Raubitschek, 2000; Zollo and Winter, 2002). With regards to the coordination and integration of NPD activities to development competences, processes relate to portfolio management, which can be described as a dynamic decision process that involves the coordination of available resources across new product projects, which are selected based on their potential value to business (Cooper, Edgett, and Kleinschmidt, 2001).

In NPD, dynamic capability research considers performance measures in relation to competitive advantage. Taking this into consideration, we focus on both internal operational efficiency (e.g. speed) capturing more short term benefits within organizational contexts (Brown and Eisenhardt, 1995; Dröge, Jayaram, and Vickery, 2004), and long-term, external competitiveness criteria (e.g. NPD program performance). Specifically, some researchers have stated that competences have a positive impact on NPD performance outcomes, namely the proportion of new product speed and new product success in the marketplace (Dröge, Jayaram, and Vickery, 2004).

Following the conceptual model, these capability dimensions are suggested to represent firms' proactive strategic abilities to cope with competitive challenges and to generate the best NPD performance through technological competence development. In addition, these strategic dimensions are also critical catalysts of short and long term NPD performance. Technological competence development is suggested to increase firms' speed and NPD program performance. Hence, the conceptual model proposes both a positive direct performance effect on strategic dimensions of firms (i.e. portfolio management, technological alignment and innovative climate) and a mediated performance effect via technological competence development in NPD.

\section{HYPOTHESES}

\section{Innovative Climate}

Siguaw, Simpson, and Enz (2006, p.560) characterize innovative climate as "composed of 
a learning philosophy, strategic direction, and transfunctional beliefs that, in turn, guide and direct all organizational strategies and actions, including those embedded in the formal and informal systems, behaviors, and competencies, and processes of the firm to promote innovative thinking and facilitate successful development, evolution, and execution of innovation." Accordingly, we expect firms with a more positive innovative climate to be more likely to increase their technological competence development as well as NPD speed.

Innovative firms focus on identifying and exploiting new product market opportunities, and are more likely to pursue really new and radical innovations, which require state of the art technology (Calantone, Garcia, and Dröge, 2003). Consequently, such firms proactively scan their environments and are more willing to make necessary investments to acquire, integrate, and reconfigure their technological knowledge to support innovation even though their efforts might result in costly failures (Grupp, 1998). Because the learning aspect of innovative climate encourages openness to innovation (Zaltman, Duncan, and Hulbek, 1973) and risk-taking behavior (Amabile, 1997; Atuahene-Giam and Ko, 2001), it stimulates experimentation with new technological ideas as well as organization-wide learning (Siguaw, Simpson, and Enz, 2006). Moreover, the creation of innovative climate is a strategic initiative that requires organizationwide commitment to innovation leading to competence development activities. Finally, innovative climate underlines the unification of various functions guided by the shared future concept of the firm and considers innovation as critical to success, which thereby leads to technological competencies (Siguaw, Simpson, and Enz, 2006). On the basis of this discussion, we propose that:

Hypothesis 1a: The higher the innovativeness of a firm, the greater its technological competence development.

The positive contribution of innovative climate to NPD speed has been noted by researchers (Calantone, Garcia, and Dr?ge, 2003; Gupta and Wilemon, 1990; Siguaw, Simpson, and Enz, 2006). However, there is little empirical research testing the direct link between them (Calantone, Garcia, and Dröge, 2003; Parry et al., 2009; Prajogo and Ahmed, 2006). Innovative firms can be characterized by their capacity to introduce new products and their willingness to devote the necessary related NPD effort and resources. The learning philosophy aspect of innovative climate reinforces openness to new ideas, allows employees to work together, and gives them the freedom to make their own decisions (Brown and Eisenhardt, 1995; Cooper, Edgett, and Kleinschmidt, 2004a), which altogether can lead to higher levels of NPD speed. Moreover, innovative climate is strategically planned to stimulate organization-wide commitment to faster innovations (Amabile, 1997; Hurley and Hult, 1998; Worren, Moore, and Cardona, 2002). Finally, innovative climate encourages the dissemination of common beliefs, values and understandings so that firms act as collective bodies (Amabile, 1997; Worren, Moore, and Cardona, 2002), and thus achieve time efficiency in carrying out their NPD activities. Accordingly, we propose that:

Hypothesis 1b: The higher the innovativeness of a firm, the higher the speed of its NPD process.

\section{Technological Alignment}

We define technological alignment as the extent to which technological developments guide a firm's NPD activities (Gatignon and Xuereb, 1997; Voss and Voss, 2000; Zhou, Yim, and 
Tse, 2005). Firms systematically monitor trends in existing technologies, identify the latest technologies, and allocate resources to product development projects accordingly to achieve an alignment between their NPD strategy and activities and technological environment (Chiesa et al., 1996; Gatignon and Xuereb, 1997). Deriving from organizational learning theory, we argue that technological alignment should affect the information that a firm acquires, evaluates and ultimately accepts or rejects. Organizational learning can be characterized as a process involving acquisition, distribution and utilization activities through which a firm's behaviour changes (Huber, 1991). Accordingly, firms with a greater technological alignment should develop better abilities in acquiring, integrating, and reconfiguring the latest technological knowledge in their product development activities. Researchers note that technology orientation encourages knowledge-learning behaviours (Noble, Sinha, and Kumar, 2002; Zhou, Yim, and Tse, 2005) and enhances competence development. Similarly, Gotteland and Boulé (2006) report a positive relationship between technological orientation and the use of knowledge about technology in NPD. In line with these studies, we further investigate this relationship and suggest that technological alignment should stimulate a firm's development of technological competence in NPD. Firms that underline the critical role of technological alignment in NPD are heavily committed to R\&D and the application of new technologies. As technological alignment becomes more important for firms, they seek to acquire new technologies and ideas, and thus increase the level of dissemination and integration of technological knowledge in NPD (Gatignon and Xuereb, 1997; Gotteland and Boulé, 2006). Accordingly, we propose that:

Hypothesis 2a: The better the technological alignment of a firm, the greater its technological competence development.

NPD speed refers to the time taken to bring a product from idea generation to market launch (Barczak, Sultan, and Hultink, 1997). Driven by the learning orientation literature, previous research has suggested that technological alignment should accelerate the information processing of firms (Noble, Sinha, and Kumar, 2002; Zhou, Yim, and Tse, 2005). That is, firms with a good level of technological alignment continuously collect information about the latest technological developments and sense the technological changes in their environment, and thus they can quickly integrate new and better technological solutions into their product development. Moreover, technological alignment enables firms to have a clearer sense of which technological areas to direct their product development activities and what direction to pursue. This accelerates the product development activities ranging from initial development efforts to ultimate commercialization. In accordance with this view, Eisenhardt (1989) also suggests that real-time information about a firm's environment should speed decision-making. However, she draws our attention to the distinction between real-time information and planning information and argues that planning information might have adverse effects on decision-making speed because it attempts to predict the future. Based on Eisenhardt's (1989) argument, we expect firms that emphasize technological alignment to search for information about future technological trends and developments, and focus on planning information. Consequently, technological alignment should slow down the NPD process. Therefore:

Hypothesis 2b: The better the technological alignment of a firm, the lower the speed of its NPD process.

\section{Project Portfolio Management}

Project portfolio management can be defined as "a dynamic decision process, whereby a 
business's list of active new product (and R\&D) projects is constantly updated and revised" (Cooper, Edgett, and Kleinschmidt, 2001, p.31). A study by Barczak, Griffin, and Kahn (2009) shows that the most popular techniques utilized by firms to review their portfolios are rank ordering of projects, discounted cash flow, and payback periods (used $65 \%, 61 \%$, and $61 \%$ of the time respectively). Although the benchmarking evidence has identified portfolio management as one of the critical NPD practices employed by the best performing firms (Barczak, Griffin, and Kahn, 2009; Cooper, 2009; Cooper, Edgett, and Kleinschmidt, 2001; Cooper, Edgett, and Kleinschmidt, 2004b; Kahn, Barczak, and Moss, 2006), there is very little, if any, empirical research on the role of portfolio management in NPD. Consequently, this study explores the link from project portfolio management to technological competence development, NPD speed and NPD program performance.

Deriving from a dynamic-capabilities perspective, which considers organizational learning as critical in creating rent-generation capabilities, we describe technological competence development as a continuous process involving the acquisition, integration, and reconfiguration of technological knowledge leading to new products (Teece, Pisani, and Shuen, 1997). It has been suggested that technological competencies require many years to become developed, and thus should be based in long term planning (Scott, 2001). Accordingly, portfolio reviews become critical for firms to be able to balance short term and long term goals associated with NPD strategy (Cooper, Edgett, and Kleinschmidt, 2001). Managing a portfolio provides firms with a strategic direction in selecting and planning new product projects, and hence determines which technologies should be acquired and developed for organization-wide learning. Moreover, portfolio management enables people to understand why they are working on a certain project by providing visibility for all projects and eliminates the communication barriers between functions, and thus enhances organization-wide learning (Cooper, Edgett, and Kleinschmidt, 2001). As such, R\&D teams are observed to gain better skills and be more successful when they are guided by portfolio planning (Kleinschmidt and Cooper, 1995). In line with these arguments, we expect portfolio management to stimulate technological competence development. Accordingly, we posit that:

Hypothesis 3a: The better the portfolio management of a firm, the greater its technological competence development.

We also propose that portfolio management increases the speed of NPD process. Poor portfolio management might result in a pipeline of many marginal-value projects, and thus might decrease the amount of resources available for the best projects (Cooper, Edgett, and Kleinschmidt, 2001). Insufficient resources, in turn, will slow down the NPD process. In contrast, effective portfolio management can enable firms to achieve the right balance between resource availability (i.e. people, days, money) and the number of projects (Barczak, Griffin, and Kahn, 2009; Cooper, Edgett, and Kleinschmidt, 2004b). For example, a study by Kessler and Chakrabarti (1999) shows that new product projects progress faster as the firm has fewer projects in its pipeline competing for resources. Moreover, portfolio reviews enable firms to select and prioritize the high-value projects and accelerate them by allocating resources accordingly (Cooper, 2009). In sum, firms can reduce the time-to-market or increase the speed of NPD processes by focusing their resources on the 'right' projects (Cooper, Edgett, and Kleinschmidt, 2001). Therefore:

Hypothesis 3b: The better the portfolio management of a firm, the higher the speed of its NPD process. 
Finally, we expect portfolio management to increase NPD program performance. Cooper, Edgett, and Kleinschmidt (2004b) show that best performers can be distinguished by their portfolio management practices. Such firms seek to create a portfolio that contains profitable, high return NPD projects for the business. Consequently, they can attain a better focus by allocating resources to the right projects. Portfolio management also enables firms to achieve the right balance in the number of incremental vs. radical projects, and short-term vs. long-term projects so that they can simultaneously proceed with several NPD projects at different phases and continuously introduce new products. Based on this discussion, we argue that portfolio management allows firms to maximize the value of the product portfolio, to efficiently allocate resources, and thus to increase the return on R\&D spending (Cooper, Edgett, and Kleinschmidt, 2001). Moreover, by achieving the right balance and focus, firms are more likely to meet customer requirements in the marketplace and increase sales (Cooper, Edgett, and Kleinschmidt, 2001; Kahn, Barczak, and Moss, 2006). Therefore:

Hypothesis 3c: The better the portfolio management of a firm, the better its NPD program performance.

\section{Technological Competence Development}

Technological competence development is defined as a firm's ability to acquire, integrate, and reconfigure technological knowledge to adapt to changing market conditions by introducing new products (Teece, Pisano, and Shuen, 1997). Technological competence consists of 'technological knowledge, trade secrets, and know-how engendered by R\&D and other technology specific intellectual property or patents protected by law' (Hsieh and Tsai, 2007, p.494). Firms can develop technological competence by either refining or extending their existing technological knowledge (i.e. exploitation) or acquiring entirely new technological knowledge (i.e. exploration) (Atuahene-Gima, 2005; March 1991). Thus, competence development involves additions to as well as modifications of a firm's existing technological knowledge, skills and/or related routines (Bond and Houston, 2003; Day, 1994; Kogut and Zander, 1992). Because technological competencies are developed through path dependent learning processes, these are valuable, rare, and sometimes unique resources for firms to achieve exceptional performance in the marketplace (Barney, 1991).

Building on the resource-based notion of valuable resources, a knowledge-based view suggests a positive link between competence development and a firm's performance (Grant, 1991). Thus, we expect a firm with unique capabilities to create and exploit technological competence to achieve a higher NPD speed as well as NPD program performance. In support of this argument, there are studies acknowledging the positive effects of experiential learning and/or process knowledge on NPD speed (Ganesan, Malter, and Rindfleisch, 2005; Hult et al., 2000; Miner, Bassoff, and Moorman, 2001). In addition, a study by Hult, Ketchen, and Arfelt (2007) reports partial support for the positive association between knowledge development and cycle time performance.

Moreover, technological competence development might lead to better NPD program performance by enabling a firm to achieve a product advantage that cannot be easily imitated by competitors (Cooper, 1985; Gatignon and Xuereb, 1997). Previous research provides evidence for the positive relationship between technological competence and NPD program performance (Calantone and di Benedetto, 1988; Calantone, Schmidt, and Song, 1996; Song and MontoyaWeiss, 2001; Song and Parry, 1997). In sum, we argue that:

Hypothesis 4a: The greater the technological competence of a firm, the higher the speed of 
its NPD process.

Hypothesis $4 \mathrm{~b}$ : The greater the technological competence of a firm, the better its NPD program performance.

\section{Speed}

As noted by several researchers (Carbonell and Rodriguez, 2006; Chen, Reilly, and Lynn, 2005; Kessler and Bierly, 2002), there is little empirical research on the consequences of NPD speed. Furthermore, the existing research produces inconsistent results about speed outcomes. Some studies indicated that speed has positive effects on NPD performance (Carbonell and Rodriguez, 2006; Kessler and Bierly, 2002; Lynn, Skov, and Abel, 1999), while others found no significant results for this relationship (Meyer and Utterback, 1995). In their study, Swink and Song (2007) investigated the relationship between the speed of each product development stage (i.e. business market analysis, technical development, product testing, and product commercialization) and project performance, and found that only the speed of technical development stage is positively related to project profitability. We further examine this relationship and suggest a positive relationship between speed and NPD program performance. The underlying premise here is that because faster new products are likely to contain the latest market ideas and technologies (Atuahene-Gima, 2003), they are more likely to be perceived as more current than competitors' (Ali, Krapfel, and LaBahn, 1995; Kessler and Bierly, 2002). Accordingly, firms with a speedy NPD process are expected to attain a better fit of its new product offerings with the market as well as higher financial results (i.e. sales and profitability) (Brown and Eisenhardt, 1995). Moreover, shorter cycle times implies that firms utilize resources efficiently and waste fewer resources on marginal activities (Swink and Song, 2007), thereby achieving greater returns. Thus, we propose that:

Hypothesis 5: The higher the speed of a firm's NPD process, the better its NPD program performance.

\section{METHODOLOGY}

\section{Data Collection}

Our sampling frame consists of 500 randomly selected firms from all nonservice firms listed in the World Business Directory. We sent a pre-survey letter to all 500 firms requesting preapproval of participation. 186 firms agreed to participate and provided a contact person. 36 companies declined to participate. 42 letters were returned due to invalid contact person or addresses. 236 companies did not respond.

In administering the final survey, we followed the total design method for survey research (Dillman, 1978). The first mailing packet included a personalized letter, the survey, a priority postage-paid envelope with an individually-typed return-address label, and a list of research reports available to participants. The package was sent by priority mail to 422 firms (186 firms agreeing to participate and 236 non-responding firms from the pre-survey). We asked the contact person (president, division manager, strategic business manager, new business program manager, or $\mathrm{R} \& \mathrm{D}$ director) to distribute the questionnaire to a manager who have been involved in developing new products in their organization or who have knowledge of overall new product programs in their organization.

To increase the response rate, we sent four follow-up mailings to the companies. One week after the mailing, we sent a follow-up letter. Two weeks after the first follow-up, we sent a 
second package with same content as the first package to all non-responding companies. After two additional follow-up letters, we received questionnaires from 164 firms, representing a response rate of $39 \%(164 / 422)$.

The industries represented in the final samples are: Chemicals and Related Products; Electronic and Electrical Equipment; Pharmaceutical, Drugs, \& Medicines; Industrial Machinery \& Equipment; Telecommunications Equipment; Semiconductors \& Computer Related Products; and Instruments and Related Products. The annual sales ranged from $\$ 500,000$ to $\$ 461$ million and the total number of employees in the business unit ranged from 11 people to 1,017 people.

Measures

Multiple item scales were developed based on new product development and strategic management literature. When pre-defined scales were unavailable to measure the factors in our research, new measures were developed using the framework proposed by Churchill (1979). Constructs were defined, an item pool was generated, and measurement formats determined. A list of items that would be potentially useful as measures was developed from the literature. The initial item pool was reviewed by a number of experts in academia and industry. On the basis of this review, some statements were dropped and others modified.

Innovative climate was measured by five items adapted from Ekvall's (1996) and Glick's (1985) studies. These items assessed the level of a firm's informal organizational arrangements that exist in its NPD system. Technological alignment was measured based on three items adopted from Cooper et al. (2004) and Albright and Kappel (2003). Together these items capture the degree to which a firm emphasises the importance of identifying technological trends and areas in its NPD related activities. Project portfolio management was measured using a five-item scale adopted from Cooper and Kleinscmidt's (1995) and Cooper et al.'s (2004) best practice scales. The three-item scale assessed the use of systematic project portfolio management by a firm's NPD function. In measuring innovative climate, technological alignment, and project portfolio management, we used a seven-point Likert scales ranging from " $1=$ Strongly Disagree" to "7 = Strongly Agree."

Technological competence development was measured by five items adopted from two sources; Kessler and Bierly (2002) and Yam et al. (2004). This measure assesses firms' capabilities to acquire new technologies and ideas as well as to disseminate this knowledge throughout their organizations. Speed performance was measured using five items, which were adopted from previous new product development research (Griffin, 1997; Kessler and Bierly, 2002). According to Griffin's study (1997), NPD processes involve 5 stages: concept generation, project evaluation, physical product development, manufacturing development and commercialization. Accordingly, NPD speed in our study is operationalized as the elapsed time between initial development efforts and the ultimate commercialization of the product relative to schedule. Finally, three items adopted from de Brentani and Kleinschmidt (2004) and Chiesa et al. (1996) were used as indicators of NPD program performance relative to objectives. These items assessed the sales, profitability and fit of the NPD program with market. We used sevenpoint Likert scales ranging from " $1=$ Not at all achieved" to " $7=$ Very well achieved" to measure technological competence development as well as speed and NPD program performance.

\section{ANALYSIS AND RESULTS}

\section{The Measurement Model}

We evaluated the psychometric properties of our measures using a confirmatory factor analysis (CFA) (Bagozzi, Yi, and Philips, 1991; Gerbing and Anderson, 1988). The CFA was fitted using the maximum likelihood estimation procedure with the raw data as input in EQS 6.1 
(Bentler, 1995). After we dropped some items that had low factor loadings or high cross loadings, the confirmatory model fitted the data satisfactorily. Table 1 details the constructs and retained items.

Insert Table 1 about here

We assessed the convergent and discriminant validity of the focal constructs by estimating a 6-factor confirmatory measurement model. Each measurement item loaded only on its latent construct. The chi-square test for our theoretical variables was not statistically significant $\left(\left({ }_{(89)}=\right.\right.$ 99.88, $\mathrm{p}>$.1). Also, the ratio of chi-square to the degrees of freedom was 1.12 (89/99.88), which was below 4. The Bentler-Bonett normed fit index (NFI), Bentler-Bonett nonnormed fit index (NNFI), the comparative fit index (CFI), Bollen's fit index (IFI), and the root mean square error of approximation (RMSEA) indicated a good fit with the hypothesized measurement model (NFI = $.88, \mathrm{NNFI}=.98, \mathrm{CFI}=.99, \mathrm{IFI}=.99$, and RMSEA $=.03)(\mathrm{Hu}$ and Bentler 1999) (Table 1). Furthermore, all the factor loadings were statistically significant $(\mathrm{p}<.01)$, and the composite reliabilities of all constructs were equal to or greater than the threshold value of .70 (Nunnally, 1978). Thus, we concluded that the measures demonstrated adequate convergent validity and reliability.

Discriminant validity was examined by calculating the shared variance between all possible pairs of constructs verifying that they were lower than the average variance extracted for the individual constructs (Fornell and Larcker 1981). These results showed that the average variance extracted by the measure of each factor was larger than the squared correlation of that factor's measure with the measures of all other factors in the model (see Table 1). Given these values, we concluded that all the factors in the measurement model possess strong discriminant validity. In light of this evaluation, we are able to conclude that all factors in the measurement model possessed both convergent and discriminant validity, and that the CFA model fitted the data adequately. Table 1 presents key results of the CFA.

\section{Hypothesis Testing}

The hypothesized model was estimated by using structural equation modeling, with the EQS 6.1 program (see Figure 1). The results of the hypothesis testing are provided in Table 2, along with parameter estimates, their corresponding t-values, and the fit statistics. Although the chi-square test was not statistically significant $\left(\left({ }^{2}(91)=100.37, \mathrm{p}>.10\right)\right.$. Also, the ratio of chisquare to the degrees of freedom was 1.10 (100.37/91), which was below 4. The Bentler-Bonett normed fit index (NNFI), Bentler-Bonett nonnormed fit index (NNFI), the comparative fit index (CFI), Bollen's fit index (IFI), and the root mean square error of approximation (RMSEA) indicated that the theoretical model had a good fit to the data $(\mathrm{NFI}=.88, \mathrm{NNFI}=.98, \mathrm{CFI}=.98$, $\mathrm{IFI}=.99$, and RMSEA $=.03)(\mathrm{Hu}$ and Bentler 1999) $($ Table 2).

Insert Table 2 about here

As reported in Table 2, a firm's innovative climate $((=.45 ; \mathrm{p}<.005)$ was found to have a significant effect on technological competence development, in support of $\mathrm{H}_{1 \mathrm{a}}$. However, its effect 
$\left((=.17 ; \mathrm{p}>.10)\right.$ on speed was not significant. Thus, $\mathrm{H}_{1 \mathrm{~b}}$ was not supported. In accordance with $\mathrm{H}_{2 \mathrm{a}}$, a firm's technological alignment was found to be positively associated with technological competence development $((=.26 ; \mathrm{p}<.05)$. In contrast, technological alignment was negatively associated with speed $\left((=-.18 ; \mathrm{p}<.10) . \mathrm{H}_{2 \mathrm{~b}}\right.$ was supported as well. Project portfolio management was found to be positively associated with technological competence development $((=.15 ; \mathrm{p}<$ $.10)$, speed $\left((=.34 ; \mathrm{p}<.005)\right.$, and NPD program performance $\left((=.26 ; \mathrm{p}<.05)\right.$. Thus, $\mathrm{H}_{3 \mathrm{a}}, \mathrm{H}_{3 \mathrm{~b}}$, and $\mathrm{H}_{3 \mathrm{c}}$ were supported.

We found technological competence to have positive effects on speed $((=.27 ; \mathrm{p}<.05)$ and NPD program performance $\left((=.41 ; \mathrm{p}<.005)\right.$, in support of $\mathrm{H}_{4 \mathrm{a}}$ and $\mathrm{H}_{4 \mathrm{~b}}$. Finally, speed was found to have no significant effect on a firm's NPD program performance $((=.01 ; p>.10)$. Thus, $\mathrm{H}_{5}$ was not supported.

\section{DISCUSSION}

This study adopts a dynamic capability view to show the drivers and performance outcomes of technological competence development. Such competence developments are particularly challenging in a current dynamic environment. This is because little is known about the defining features or attributes of technological competence development which are unique to each firm. These are intangible and interaction based and so mistakes are costly and timely, and regaining lost ground on competitors is difficult. Moreover, we suggest that this happens in conjunction with, and is facilitated by, a set of firms' strategic dimensions of resources and capabilities. Apart from two hypotheses, all others proposed in this study are supported by data.

Several of the hypotheses focus on how the strategic dimensions of firms' dynamic capabilities impact on technological competence development and accelerate NPD performance. For example, the creation of an appropriate climate enhances the technological competence development (Hypothesis 1a) and speed of its NPD process (Hypothesis 1b). The result is an innovative work environment that enables firms to seize and exploit new technological knowledge in-line with product and market opportunities (Miles and Snow, 1978). Contrary to our expectations, innovative climate does not lead to higher levels of speed. This result also indicates that an innovative environment does not directly impact on NPD speed, although a strong indirect performance effect was observed. This result differs from the findings of previous studies that confirm that a strong orientation toward innovation allows employees to work together and give them the freedom to make their own work-related decisions as well as the time to enhance new product success (i.e. Calantone, Garcia, and Dröge, 2003; Gupta and Wilemon, 1990; Parry et al., 2009; Zhou, Yim, and Test 2005). For example, Calantone, Garcia, and Dröge's (2003) study also confirmed that innovativeness is positively related to NPD speed. The development of technological competence might have a mediating role relating to changes in the environment. One explanation for the indirect performance effect could be that for developing technological competence, where goals are often unclear, there needs to be a certain amount of time and effort to determine all possible alternatives. Occasional divergent interpretations and subsequent conflicts between employees might also impede this enhancement and development process. We can conclude that developing an innovative NPD climate increases NPD speed through developing technological competence.

Drawing from the broader learning literature (i.e. organizational learning and learning orientation), we offer a link from technological alignment to technological competence development and speed (Hypothesis $2 \mathrm{a}$ and $2 \mathrm{~b}$ respectively). The results were in accordance with our expectations. Technological alignment is found to increase technological competence development, which is consistent with Danneels' (2002) suggestion that when a firm performs a 
broad technological search for NPD, the learning activities add new competences for the firm. Also as expected, technological alignment appears to reduce NPD speed. This is in-line with Kessler, Bierly, and Shanthi's (2000, p.215) suggestion that 'the process of external learning will slow down the new product development process in the later stages, such as technology development, than the earlier stages, such as idea generation'. Hence, aligning technology too tightly with a product strategy, emphasizing the frequent and systematic monitoring of trends in existing technologies to identify emerging technologies, could lead to reduced NPD speed (Chiesa, Coughlan, and Voss, 1996).

Several of the hypotheses describe how portfolio management positively influences technological competence development, speed and NPD program performance (Hypotheses 4a, $4 \mathrm{~b}$, and $4 \mathrm{c}$ ). These findings are critical to understanding the role of portfolio management in NPD. That is, firms that are able to implement the portfolio method are more likely to identify, integrate and reconfigure their technological knowledge (Cooper, 2009; Parry et al. 2009; Quiantana-Garcia and Benavides-Velasco, 2008). The data suggest that managers experience reduced NPD speed when they favour portfolio management in their technological competence development process. Furthermore, good portfolio management practices in NPD help firms to priorities their projects as well as guide them about how to allocate human and other resources (Kahn, Barczak, and Moss, 2006; Parry et al. 2009). On the other hand, if firms fail to manage project portfolios and cannot make efficient and effective resource allocation decisions, they might expect long cycle times, high failure rates and unsustainable new program failures over a period of time (Barczak, Kahn, and Moss, 2006; Cooper, Edgett, and Kleinschmidt, 1998).

Finally, the findings are not consisted with an earlier study by Calantone, Garcia and Dröge's (2003) that predicted a positive relationship between NPD speed and NPD program performance (Hypothesis 5). A little surprising is our finding that the duration of NPD processes suffers from poor NPD program performance when dynamic capabilities dimensions vary. We would rather expect that firms that have the capabilities to switch technology when needed, and follow their technological competence trends and developments, will enhance their program performance. It could be, however, that such firms are instead primarily focusing on organizational competence development (Winter, 2003) or market competence development (Day, 1994). Such competence development does not necessarily meet the quality, delivery and price expectations of customers immediately (Christensen, 1997) because the technology and markets are new and unfamiliar for new product development, which could increase elapsed times.

\section{CONCLUSIONS AND FUTURE WORK}

Based on a review of the dynamic capabilities and NPD literature, this study examined the factors that impact technological competence development and NPD speed, and how they affect NPD success. A dynamic capability perspective used the following to explain these factors: innovative climate, technological alignment and portfolio management. Past research studies have largely ignored the relationship between the strategic dimensions of dynamic capabilities, and firms' technological competence development and success in the context of NPD.

The analysis, based on data collected from 164 firms, show that the creation of an appropriate climate for innovation, the better technological alignment with NPD and the use of project portfolio management all contributed to the development of technological competence. Our model also specified that innovative climate, technological alignment and portfolio management are antecedents to both technological competence development and NPD speed, which in turn are antecedents to NPD program performance. The results also found that the indirect effects of innovative climate, technological alignment and portfolio management on NPD 
speed occur through technological competence development.

Research contributes to the debate on how to define and measure technological competence. We extend the technological competence development conceptualization from its application to research and development expenditures, citations counts, and patents (Coombs and Bierly, 2006; Hobday and Rush, 2007) to a more comprehensive measure. In this paper, we adopt a conceptualization of technological competence to develop our arguments about where they originate and how they evolve through organizational learning. Coombs and Bierly (2006) showed that practitioners and academics recognize that there are many possible measures of technological competence, each of which might be appropriate for different types of products, contexts and firms. The dynamic capability perspective on competence development presented in this article elaborates on the rationale behind learning, opportunity recognition and reconfigurations of firms' resources.

Furthermore, previous research on new product development has generally considered the development process factors or organizational competence development as antecedents of new product performance (Brown and Eisenhardt, 1995). Few if any studies have investigated the nature of technological competence development as antecedent of new product performance. Our study contributes to this research stream by broadening it beyond the more prosaic factors to highlight the important role that technological competence development plays in enhancing new product speed and NPD program performance.

Our study has several managerial implications. Our findings could serve as a guide for technological competence development in NPD. Technological competence development is one of a firm's most important dynamic capabilities. It requires understanding and sensing opportunities, as well as a collective, organization-wide learning for new product development. It is about finding new ways to reconfigure firms' tangible and intangible resources. In particular, our findings highlight three essential drivers of a firm's ability to develop technological knowledge and competences: technological alignment, innovative climate and portfolio management. Firms need to concentrate their efforts on these three drivers. Since there are complimentary interrelationships as well as conflicts between these drivers, managers need to develop a better understanding of which drivers they need to build and emphasize the most to seize and detect opportunities, or how to enhance and reconfigure resources to remain competitive.

\section{Implications for Future Research}

Our analysis indicates that the different internal (i.e. innovative climate, portfolio management) and external (i.e. technological alignment) dimensions of dynamic capabilities significantly influence technological competence development. The three dynamic capabilities dimensions that were analyzed in this article offer different but complementary paths to various types of NPD speed and program performance. The specific links between them and technological competence development will be extended in future research.

One research limitation was the geographic scope, which was restricted to North American firms. Future work should extend the analysis of the observed mediated role of technological competence to other geographic regions. For example, how does the innovativeness of firms appear in European, Far Eastern, South American, and Pacific Rim nations? What are their product portfolios? How do these factors (i.e. innovativeness and project portfolio management) affect technological competence development, and what are their effects on speed and NPD program performance? Since the data used in this study is cross-sectional, the firms included in the sample might be at various stages of technological competence development. To avoid this, future research should consider longitudinal data to understand how technological competence 
development takes place and accumulates over time. With multi-time data, it would be possible to address such questions as: How does technological competence actually develop over time from concept to implemented reality? Do firms acquire competences in different processes sequentially? 


\section{Table 1: Results of the CFA}

\begin{tabular}{|c|c|c|c|}
\hline & Scale Items & $\begin{array}{l}\text { Standardized } \\
\text { Loading }\end{array}$ & $\begin{array}{l}\text { t-value } \\
\text { a }\end{array}$ \\
\hline $\begin{array}{l}\text { Innovative } \\
\text { Climate }\end{array}$ & $\begin{array}{l}\text { There is time for people to develop } \\
\text { unplanned new ideas. }\end{array}$ & .61 & 5.43 \\
\hline $\begin{array}{l}\mathrm{AVE}=50.6 \% \\
\mathrm{HSV}=33.0 \% \\
\mathrm{CR}=.70\end{array}$ & $\begin{array}{l}\text { There is a strong support for further } \\
\text { development of new ideas. }\end{array}$ & .80 & 6.61 \\
\hline $\begin{array}{l}\text { Technological } \\
\text { Alignment }\end{array}$ & $\begin{array}{l}\text { We clearly identify technological areas } \\
\text { that focus our NPD efforts. }\end{array}$ & .88 & 8.34 \\
\hline $\begin{array}{l}\mathrm{AVE}=74.8 \% \\
\mathrm{HSV}=18.0 \% \\
\mathrm{CR}=.90\end{array}$ & $\begin{array}{l}\text { Future technological trends are important } \\
\text { in our NPD planning. }\end{array}$ & .85 & 8.11 \\
\hline $\begin{array}{l}\text { Project } \\
\text { Portfolio }\end{array}$ & $\begin{array}{l}\text { We have clearly defined goals for all our } \\
\text { individual new products. }\end{array}$ & .80 & 9.24 \\
\hline $\begin{array}{l}\text { Management } \\
\mathrm{AVE}=67.9 \%\end{array}$ & $\begin{array}{l}\text { Systematic project portfolio management is } \\
\text { in place. }\end{array}$ & .80 & 9.24 \\
\hline $\begin{array}{l}\mathrm{HSV}=20.0 \% \\
\mathrm{CR}=.90\end{array}$ & $\begin{array}{l}\text { The project portfolios are aligned with the } \\
\text { business strategy. }\end{array}$ & |.87 & 10.36 \\
\hline $\begin{array}{l}\text { Technological } \\
\text { Competence } \\
\text { Development }\end{array}$ & $\begin{array}{l}\text { Our competence to explore new technological } \\
\text { developments from inside the BU is well } \\
\text { developed. }\end{array}$ & 1.76 & 8.74 \\
\hline $\begin{array}{l}\mathrm{AVE}=67.2 \% \\
\mathrm{HSV}=33.0 \%\end{array}$ & $\begin{array}{l}\text { We can pass lessons learned on across } \\
\text { organizational boundaries. }\end{array}$ & .92 & 11.52 \\
\hline $\mathrm{CR}=.90$ & We can pass lessons learned on over time. & .77 & 8.97 \\
\hline $\begin{array}{l}\text { Speed } \\
\text { Performance }\end{array}$ & $\begin{array}{l}\text { Scheduled time is in line with total } \\
\text { development time (TT). }\end{array}$ & .65 & 7.02 \\
\hline $\mathrm{AVE}=61.4 \%$ & Our Development time (DT) is satisfactory. & .72 & 7.92 \\
\hline $\begin{array}{l}\mathrm{HSV}=20.0 \% \\
\mathrm{CR}=.80\end{array}$ & Our Total Time (TT) is satisfactory. & .95 & 11.30 \\
\hline $\begin{array}{l}\text { NPD Program } \\
\text { Performance }\end{array}$ & $\begin{array}{l}\text { Our new products meet customer } \\
\text { requirements. }\end{array}$ & .73 & 7.79 \\
\hline $\begin{array}{l}\mathrm{AVE}=55.9 \% \\
\mathrm{HSV}=26.0 \%\end{array}$ & $\begin{array}{l}\text { The impact of our NPD program on our sales } \\
\text { level is positive. }\end{array}$ & .85 & 9.40 \\
\hline $\mathrm{CR}=.80$ & $\begin{array}{l}\text { We get good returns from our NPD program } \\
\text { relative to our spending on it. }\end{array}$ & .65 & 6.85 \\
\hline \multicolumn{4}{|c|}{ Model Fit Statistics: $\quad(2=99.88(\mathrm{df}=89, \mathrm{p}>.10)$} \\
\hline \multicolumn{4}{|c|}{$\mathrm{NFI}=.88$} \\
\hline \multicolumn{4}{|l|}{$\mathrm{NNFI}=.98$} \\
\hline \multicolumn{4}{|l|}{$\mathrm{CFI}=.99$} \\
\hline \multicolumn{4}{|l|}{$\mathrm{IFI}=.99$} \\
\hline \multicolumn{4}{|l|}{ RMSEA $=.03$} \\
\hline $90 \% \mathrm{CI}$ of $\mathrm{RI}$ & $(.00, .07)$ & & \\
\hline
\end{tabular}

aThe $\mathrm{t}$-values from the unstandardized solution;

Notes: $\mathrm{AVE}=$ Average variance extracted $; \mathrm{HSV}=$ Highest shared variance with other constructs; $\mathrm{CR}=$ Composite reliability. 
Table 2: Results of Hypothesis Testing

[pic]

\section{Dependent Variables}

Technological

NPD

Independent Competence Speed Program

Variables Development Performance Performance Hypotheses Conclusion [pic]

Innovative Climate $.45^{* * *}(3.12)$

$$
\text { .17n.s. (1.14) } \quad \mathrm{H}_{1 \mathrm{~b}} \quad \text { Not supported }
$$

Technological

$.26^{* *}(2.42)$

$\mathrm{H}_{2 \mathrm{a}} \quad$ Supported

Alignment

$-.18^{*}(-1.56)$

$\mathrm{H}_{2 \mathrm{~b}} \quad$ Supported

Project Portfolio

$.15^{*}(1.34)$

$\mathrm{H}_{3 \mathrm{a}} \quad$ Supported

Management

$.34^{* * *}(2.86)$

$\mathrm{H}_{3 \mathrm{~b}} \quad$ Supported

$.26^{* *}(2.10) \quad \mathrm{H}_{3 \mathrm{c}} \quad$ Supported

Technological Competence

Development

$.27^{* *}(1.88)$

$.41^{* * *}(3.23) \quad \mathrm{H}_{4 \mathrm{~b}} \quad$ Supported

Speed Performance

.01n.s. $(.06) \quad \mathrm{H}_{5} \quad$ Not supported

Model Fit Statistics: $\left({ }^{2}=100.37(\mathrm{df}=91, \mathrm{p}>.10)\right.$

$\mathrm{NFI}=.88$

$\mathrm{NNFI}=.98$

$\mathrm{CFI}=.99$

$\mathrm{IFI}=.99$

RMSEA $=.03$

$90 \%$ CI of RMSEA $=(.00, .06)$

[pic]

Notes: ${ }^{* *} p<.005 ;{ }^{* *} p<.05 ;{ }^{*} p<.10 ;$ n.s.: Not significant (1-tailed test); t-values are in parentheses. 
Figure 1: Antecedents and Consequences of Technological Competence Development in NPD

[pic]

Notes: ${ }^{* * *} \mathrm{p}<.005 ;{ }^{* *} \mathrm{p}<.05 ;{ }^{*} \mathrm{p}<.10 ;{ }^{\text {n.s. }}$. Not significant (1-tailed test); $\mathrm{t}$-values are in parentheses. 


\section{References}

Ali, Abdul, Krapfel, Robert Jr. and LaBahn, Douglas (1995). Product innovativeness and entry strategy: Impact on cycle time and break-even time. Journal of product innovation management, 12(1), 54 -70.

Amabile, Teresa M. (1997). Motivating creativity in organizations: On doing what you love and loving what you do. California management review, 40(1), 39-58.

Albright, Richard E. and Kappel, Thomas A. (2003). Roadmapping in the corporation. Research technology management, 46 (2), 31.

Atuahene-Gima, Kwaku and Ko, Anthony (2001). An empirical investigation of the effect of market orientation and entrepreneurship orientation alignment on product innovation. Organization science, 12(1), $54-74$.

Atuahene-Gima, Kwaku (2003). The effects of centrifugal and centripetal forces on product development speed and quality: How does problem solving matter? Academy of management journal, 46(3), 359-373.

Atuahene-Gima, Kwaku (2005). Resolving the capability - rigidity paradox in new product innovation. Journal of marketing, 69(4), 61-83.

Bagozzi, Richard P., Yi, Youjae and Phillips, Lynn W. (1991). Assessing construct validity in organizational research. Administrative science quarterly, 36, 421-58.

Barczak, Gloria, Sultan, Fareena, and Hultink, Erik Jan (2007). Determinants of IT usage and new product performance. Journal of product innovation management, 24, 600-613.

Barczak, Gloria, Griffin, Abbie and Kahn, Kenneth B. (2009). Perspcetive: Trends and drivers of success in NPD practices: Results of the 2003 PDMA best practices study. The journal of product innovation management, 26(1), 3 - 23.

Barney, Jay (1991). Firm resources and sustained competitive advantage. Journal of management, 17, 99.

Bond, Edward U. and Houston, Mark B. (2003). Barriers to matching new technologies and market opportunities in established firms. Journal of product innovation management, 20(2), 120-135.

Brentani, Ulrike and Kleinschmidt, Elko J. (2004). Corporate culture and commitment: Impact on performance of international new product development programs. Journal of product innovation management, 21(5), 309-333.

Brown, Shona L. and Eisenhardt, Kathleen M. (1995). Product development: Past research, present findings, and future directions. The academy of management review, 20(2), 343-378.

Bentler, Peter M. (1995). EQS structural equations program manual. Encino, CA: Multivariate software, Inc.

Calantone, Roger J. and Di Benedetto, Anthony (1988). An integrative model of the new product development process an empirical validation. Journal of product innovation management, 5(3), 201-215.

Calantone, Roger J., Schmidt, Jeffrey B. and Song, X. Michael (1996). Controllable factors of new product success: A cross-national comparison. Marketing science, 15(4), 341-358.

Calantone, Roger, Garcia, Rosanna and Dr?ge, Cornelia (2003). The effects of environmental turbulence on new product development strategy planning. Journal of product innovation management, 20(2), 90 103.

Carbonell, Pilar and Rodriguez, Ana Isabel (2006). The impact of market characteristics and innovation speed on perceptions of positional advantage and new product performance. International journal of research in marketing, 23(1), 1-12.

Chen, Jiyao, Reilly, Richard R. and Lynn, Gary S. (2005). The Impacts of speed-to-market on new product success: The moderating effects of uncertainty. IEEE transactions on engineering management, 52(2), 199-212.

Chiesa, Vittorio, Coughlan, Paul and Voss, Chris A. (1996). Development of a technical innovation audit. Journal of product innovation management, 13(2), 105-136.

Christensen, Clayton M. (1997). The innovator's dilemma. Cambridge, MA: Harvard business school press. 
Coombs, Joseph E. and Bierly, Paul E. (2006). Measuring technological capability and performance. R\&D management, 36(4), 421-438.

Cooper, Robert G. (1985). Selecting winning new product projects: Using the newprod system. Journal of product innovation management, 2, 34-44.

Cooper, Robert G., Edgett, Scott J. and Kleinschmidt, Elko J. (1998). Portfolio management for new products. Reading, Massachusetts: Addison-Wesley.

Cooper, Robert, Edgett, Scott J. and Kleinschmidt, Elko J. (2001). Portfolio management for new product development: Results of an industry practice study. R\&D management, 31(4), 361-380.

Cooper, Robert, Edgett, Scott, and Kleinschmidt, Elko. (2001). Portfolio management for new product development: Results of an industry practices study. R\&D management, 31(4), 361

Cooper, Robert, Edgett, Scott, and Kleinschmidt, Elko J. (2004a). Benchmarking NPD practices-I. Research technology management, 47(1), 31-43.

Cooper, Robert, Edgett, Scott, and Kleinschmidt, Elko J. (2004b). Benchmarking NPD practices-II. Research technology management, 47(3), 50-59.

Cooper, Robert G. (2009). How companies are inventing their idea-to-launch methodologies. Research technology management, March-April, 47-57.

Cooper, Robert G. (2009). How companies are reinventing their idea-to-launch methodologies. Research technology management, March-April, 47-57.

Danneels, Erwin (2002). The dynamics of product innovation and firm competences. Strategic management journal, 23(12), 1095-1121.

Danneels, Erwin (2007). The process of technological competence leveraging. Strategic management journal, 28, 517-533.

Day, George S. (1994). The capabilities of market-driven organizations. Journal of marketing, 58(4), 37.

Dillman, Don A. (1978). Mail and telephone surveys: The total design method. New York: John Wiley \& Sons.

Dröge, Cornelia, Jayaram, Jayanth and Vickery, Shawnee K. (2004). The effects of internal versus external integration practices on time-based performance and overall firm performance. Journal of operations management, 22(6), 557-573.

Easterby-Smith, Mark and Prieto, Isabel M. (2008). Dynamic capabilities and knowledge management: An integrative role for learning? British journal of management, 19, 235- 249.

Eisenhardt, Kathleen M. (1989). Making fast strategic decisions in high velocity environments. Academy of management journal, 32(3), 543-576.

Eisenhardt, Kathleen M. and Martin Jeffrey A. (2000). Dynamic capabilities: What are they? Strategic management journal, 21, 1105- 1121.

Galunic, Charles and Rodan, Simon (2004). Resource recombination in the firm: Knowledge structures and potential for Schumpeterian innovation. Strategic management journal, 19(2), 1193-1201.

Ganesan, Shankar, Malter, Alan J., and Rindfleisch, Aric (2005). Does distance still matter? Geographic proximity and new product development. Journal of marketing, 69(4), 44-60.

Garcia, Rosanna, Calantone, Roger, and Levine, Ralph (2003). The role of knowledge in resource allocation to exploration versus exploitation in technologically oriented organizations. Decision sciences, $34(2), 323$.

Gatignon, Hubert and Xuereb, Jean Michael (1997). Strategic orientation of the firm new product performance. Journal of marketing research, 34(1), 77 - 90.

Gerbing, David W. and Anderson, James C. (1988). An updated paradigm for scale development incorporating unidimensionality and its assessment. Journal of marketing research, 25(2), 186-192.

Gotteland, David and Boule, Jean-Marie (2006). The market orientation-new product performance relationship: Redefining the moderating role of environmental conditions. International journal of 
research in marketing, 23(2), 171- 185.

Grant, Robert M. (1991). The resource-based theory of competitive advantage: Implications for strategic formulation. California management review, 33, 114-135.

Grant, Robert M. (1996). Toward a knowledge-based theory of the firm. Strategic management journal, 17, 109-122.

Gupta, Ashok K., and Wilemon, David L. (1990). Accelerating the development of technologybased new products. California management review, 32(2), 24-44.

Helfat, Constance E. (1997). Know-how and asset complementarity and dynamic capability accumulation: The case of R\&D. Strategic management journal, 18, 339 - 360.

Helfat, Constance E. and Raubitschek, Ruth S. (2000). Product sequencing: Co-evolution of knowledge, capabilities and products. Strategic management journal, 21(10/11), 961-979.

Hobday, Michael and Rush, Howard (2007). Upgrading the technological capabilities of foreign transnational subsidiaries in developing countries: The case of electronics in Thailand. Research policy, 36(9), 1335-1356.

Huber, George P. (1991). Organizational learning: The contributing processes and the literatures. Organization science, 2, 88-115.

Hult, G. Tomas M., Hurley, Robert F., Giunipero, Lary C., and Nichols, Ernest L. Jr. (2000). Organizational learning in global purchasing: A model and test of internal users and corporate buyers. Decision sciences, 31(2), 293-325.

Hult, G. Tomas M., Ketchen, David J., and Arrfelt, Mathias (2007). Strategic supply chain management: Improving performance through a culture of competitiveness and knowledge development. Strategic management journal, 28(10), 1035-1052.

Hurley, Robert F. and Hult, G. Thomas (1998). Innovation, market orientation, and organizational learning: An integration and empirical examination. Journal of marketing 62(3), 42-54.

Kessler, Eric H. and Chakrabarti, Alok K. (1999). Speeding up the pace of new product development. Journal of product innovation management, 16(3), 231-247.

Kessler, Eric H., Bierly, Paul E., and Shanthi, Gopalakrishnan (2000). Internal vs. external learning in new product development: Effects on speed, costs and competitive advantage. R\&D management, 30(3), 213223.

Kessler, Eric H. and Bierly, Paul E. (2002). Is faster really better? An empirical test of the implications of innovation speed. IEEE transactions on engineering management, 49(1), 2-12.

Kim, Linsu (1997). The dynamics of Samsung's technological learning in semiconductor. California management review, 39(3), 86-100.

Kleinschmidt, Elko J. and Cooper, Robert G. (1995). The relative importance of new product success determinants - perception versus reality. R \& D management, 25(3), 281.

Kogut, Bruce and Zander, Udo (1992). Knowledge of the firm, combinative capabilities, and the replication of technology. Organization science, 3, 383-397.

Li, Tiger and Calantone, Roger J. (1998). The impact of market knowledge competence on new product advantage: Conceptualization and empirical examination. Journal of marketing, 62(4), 13-29.

Lynn, Gary S., Skov, Richard B., and Abel, Kate D. (1999). Practices that support team learning and their impact on speed to market and new product success. Journal of product innovation management, 16(5), 439-454.

March, James G. (1991). Exploration and exploitation in organizational learning. Organization science, 2, 71-87.

McEvily Susan K., Eisenhardt, Kathleen M., and Prescott, John E. (2004). The global acquisition, leverage, and protection of technological competencies. Strategic management journal, 25(8/9), 713-722.

Meyer, Marc H. and Utterback, James M. (1995). Product development cycle time and commercial success. IEEE transactions on engineering management, 42(4), 297-304. 
Miles, Raymond E. and Snow, Charles C. (1978). Organizational strategy, structure, and process. New York: McGraw-Hill.

Miner, Anne S., Bassoff, Paula and Moorman, Christine. (2001). Organizational improvisation and learning: A field study. Administrative science quarterly, 46(2), 304-373.

Montoya-Weiss, Mitzi and Roger Calantone (1994). Determinants of new product performance: A review and meta-analysis. Journal of product innovation management, 11:5, 397-417.

Nelson, Richard R. (1991). Why do firms differ, and how does it matter? Strategic management journal, 12, 61-74.

Nelson, Richard R. and Winter, Sidney G. (1982). An evolutionary theory of economic change. Cambridge, MA: Harvard business school.

Noble, Charles H., Sinha, Rajiv K. and Kumar Ajith (2002). Market orientation and alternative strategic orientations: A longitudinal assessment of performance implications. Journal of marketing, 66(4), 25-39.

Nunnally, Jum C. (1978). Psychometric theory. New York: McGraw-Hill.

Parry, Mark, Song, Michael, de Weerd-Nederhof, Petra C., and Visscher, Klaasjan (2009). The impact of NPD strategy, product strategy, and NPD processes on perceived cycle time. Journal of product innovation management (forthcoming).

Prahalad, C. K. and Hamel, Gary (1990). The core competence of the corporation. Harvard business review, 68(3), 79-91.

Pisano, Gary P. (1994). Knowledge, integration, and the locus of learning: An empirical analysis of process development. Strategic management journal, 15(8), 85-100.

Prajogo, Daniel I. and Ahmed, Pervaiz K. (2006). Relationships between innovation stimulus, innovation capacity, and innovation performance. R\&D management, 36(5), 499-515.

Ruttan, Vernon W. (1997). Induced innovation, evolutionary, theory and path dependence: source of technical change. Economic journal, 107 (444), 1520-1529.

Quiantana-Garcia C. and Benavides-Velasco C.A. (2008). Innovative competence, exploration and exploitation: The influence of technological diversification. Research policy, 37, 492-507.

Salomo, Soren, Talke, Katrin, and Strecker, Nanja (2008). Innovation field orientation and its effect on innovativeness and firm performance. Journal of product innovation management, 25 (6), 560-576.

Sanchez, Ron and Heene, Aime (1997). Managing for an uncertain future: A systems view of strategic organizational change. International studies of management \& organization, 27, 21- 42.

Schilling, Melissa A. (1998). Technological lockout: an integrative model of economic and strategic factors driving technology success and failure. Academy of management review, 23(2), 267-284.

Schreyögg, Georg and Kliesch-Eberl, Martina (2007). How dynamic can organizational capabilities be? Towards a dual-process model of capability dynamization. Strategic management journal, 28(9), 913933.

Scott, George M. (2001). Strategic planning for technology products. R\&D management, 31(1), 15-26.

Siguaw, Judy A., Simpson, Penny M. and Enz, Cathy A. (2006). Conceptualizing innovation orientation: A framework for study and integration of innovation research. Journal of product innovation management, 23(6), 556-574.

Song, X. Michael and Parry, Mark E. (1997). The determinants of Japanese new product success. Journal of marketing research, 34(1), 64-76.

Song, X. Michael and Montoya-Weiss, Mitzi M. (2001). The effects of perceived technological uncertainty on Japanese new product development. Academy of management journal, 44(1), 61-80.

Song, X. Michael, Dröge, Cornelia, Hanvanich, Sangphet and Calantone, Roger (2005). Marketing and technology resource complementarity: An analysis of their interaction effect in two environmental contexts. Strategic management journal, 26(3), 259-276.

Swink, Morgan and Song, X. Michael (2007). Effects of marketing-manufacturing integration on new 
product development time and competitive advantage. Journal of operations management, 25(1), 203217.

Teece, David and Pisano, Gary (1994). The dynamic capabilities of firms: An introduction. Industrial and corporate change, 3, 537-556.

Teece, David, Pisano, Gary, and Shuen, Amy (1997). Dynamic capabilities and strategic management. Strategic management journal, 18(7), 509-533.

Voss, Glenn B. and Voss, Zannie Giraud (2000). Strategic orientation and firm performance in an artistic environment. Journal of marketing, 64(1), 67-83.

Worren, Nicolay, Moore, Karl and Cardona, Pablo (2002). Modularity, strategic flexibility, and firm performance: A study of the home appliance industry. Strategic management journal, 23(12), 1123-1140.

Yam, R. C. M., Guan, J. C., Pun, K. F., and Tang, E. P. Y. (2004). An audit of technological innovation capabilities in Chinese firms: some empirical findings in Beijing, China. Research policy, 33(8), 11231140 .

Zahra, Shaker A. (1996). Technology strategy and new venture performance: A study of corporatesponsored and independent biotechnology ventures. Journal of business venturing, 11, 289-321.

Zaltman, Gerald, Duncan, Robert, and Holbek, Jonny (1973). Innovations and organizations. New York: John Wiley \& Sons Inc.

Zhou, Kevin Zheng, Yim, Chi Kin, and Tse, David K. (2005). The effects of strategic orientations on technology- and market-based breakthrough innovations. Journal of marketing, 69, 42-60.

Zollo, Maurizio and Winter, Sidney G. (2002). Deliberate learning and the evolution of dynamic capabilities. Organization science, 13(3), 339-351.

\author{
NPD \\ Program Performance
}

Technological Competence Development

Speed Performance

Innovative Climate

Project Portfolio Management

Technological Alignment 


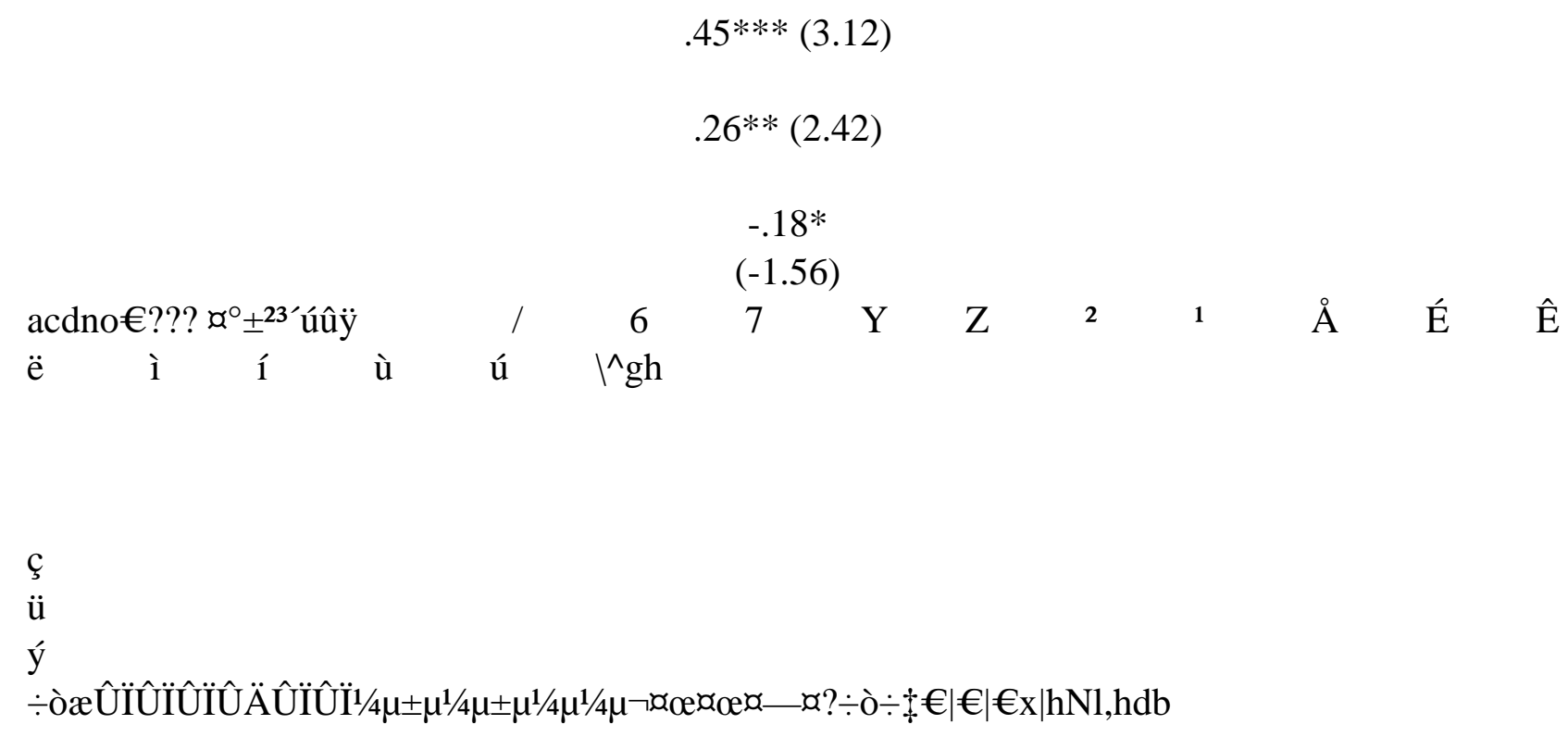


h-Çhdbh[Øhdb5?h?>\#h»"6

.17 n.s. $(1.14)$
$.15^{*}(1.34)$
$.34 * * *(2.86)$
$.27 * *$
$(1.88)$
$.41 * * *$
$(3.23)$
$.01 \mathrm{n} . \mathrm{s}$.
$(.06)$
$.26 * *$
$(2.10)$

